[Agr. Biol. Chem., Vol. 30, No. 3, p. 307 308 1966]

\title{
Inhibition of Phage Growth of Butanol-producing Bacterium, Using Oxytetracycline- resistant Mutants
}

Sir:

Inhibiting the phage growth in the industrial fermentations is an important question. A method is to add some chemical substances to the medium which suppress the phage growth without inhibiting the growth and fermentation of host bacteria. However, few successful results have been reported.

In the butanol fermentation using Clostridium saccharoperbutylacetonicum, we found the antibiotic, chloramphenicol, available for the growth inhibition of HM-phages infecting this bacterium. ${ }^{1}$ In this case the host strains were constitutionally resistant to chloramphenicol. By using mutant strains resistant to antibiotics, similar selective inhibition of the phage growth may be obtained. In fact such instances were shown by Brock ${ }^{2}$ and Brock et $\mathrm{al}^{3)}$ in some bacteria resistant to streptomycin, but not in bacteria employed industrially.

In this communication we report that the growth of phage of butanol-producing bacterium was inhibited by using host strains resistant to oxytetracycline. In this case the use of streptomycin-resistant strain was not successful.

Phage HM 2 and its host strain N1-4 of $\mathrm{Cl}$. saccharoperbutylacetonicum ${ }^{4)}$ were used. TYA medium $^{4}$ was used. The phage and bacterium were assayed by the modified double layer method. ${ }^{5}$ ) One-step growth experiment was

1) A. Murata and M. Hongo, This Journal 28, 190 (1964) 2) T.D. Brock, Biochem. Biophys. Res. Commun., 9, 184 (1962).

3) T.D Brock, J. Mosser and B. Peacher, J. Gen. Microbiol., 33, 9 (1963).

4) M. Hongo and A. Murata, This Journal 29, 1135 (1965).

5) M. Hongo and A. Murata, ibid., 29, 1140 (I965). carried out according to the modified method. ${ }^{6)}$ All incubations were at $30^{\circ} \mathrm{C}$.

About ten of one-step mutants, resistant to $30 \mu \mathrm{g}$ of oxytetracycline per $\mathrm{ml}$, were isolated by plating a large populations of cells $\left(1 \times 10^{8}\right)$ on agar medium containing $30 \mu \mathrm{g}$ of the antibiotic per $\mathrm{ml}$, and picking colonies. The mutants grew well in broth containing the same concetration of the antibiotic, although the original strain was completely inhibited by $1 \mu \mathrm{g}$ of oxytetracycline per $\mathrm{ml}$.

Mutants termed type A did not permit phage growth in the presence of oxytetracycline, whereas they permitted it in the

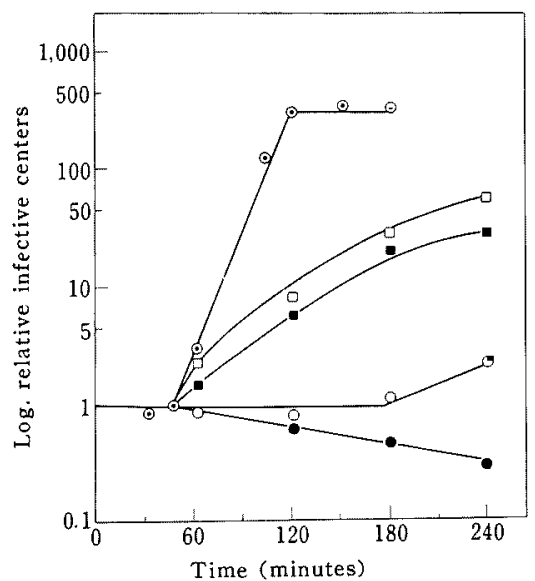

FIG. 1. One-step Growth Curves of Phage HM 2 in the Presence of Oxytetracycline, using Host Strain Resistant to the Antibiotic.

$$
\begin{array}{ll}
\text { no antibiotic } & \square 2 \mu \mathrm{g} / \mathrm{ml} \\
5 \mu \mathrm{g} / \mathrm{ml} & \bigcirc 10 \mu \mathrm{g} / \mathrm{ml} \\
20 \mu \mathrm{g} / \mathrm{ml} &
\end{array}
$$

Host strain used was resistant to $30 \mu \mathrm{g} / \mathrm{ml}$ of the antibiotic. Antibiotic was added just prior to adsorption.

6) M. Hongo, T. Miyamoto and A. Murata. This Journal, $\mathbf{3 0}$, in press. 
absence of the antibiotic. The minimum concentration of the antiabiotic necessary to inhibit the phage growth was approximately $10 \mu \mathrm{g}$ per $\mathrm{ml}$, as shown in Fig. 1. This indicates that oxytetracycline has a specific antiviral effect.

Another type of mutant strains was also encountered. In these strains termed type B the development of resistance to oxytetracycline was associated with a simultaneous loss of sensitivity to phage $\mathrm{HM}$ 2, although the strains had never been in contact with the phage. No plaques were formed on plates even when $10^{8}$ plaque-forming units (PFU)

TABLE I. SOLVENTS YIELD OF OXYTETRACYCLINERESISTANT STRAINS

Yield based on sugar added (\%)

$\begin{array}{lcccc}\text { Strain } & \begin{array}{c}\text { Total } \\ \text { solvents }\end{array} & \text { Butanol } & \begin{array}{c}\text { Ace- } \\ \text { tone }\end{array} & \text { Ethanol } \\ \text { (N1-4) } & (36.9) & (29.0) & (6.6) & (1.3) \\ \text { N1-4/OTC(Type A)* } & 35.7 & 25.0 & 9.2 & 1.5 \\ \text { N1-4/OTC(Type B)** } & 36.8 & 28.7 & 6.8 & 1.4\end{array}$

TYA medium (sugar $3.9 \%$, no OTC) $100 \mathrm{ml}$, inoculum $10 \mathrm{ml}$, no phage, $30^{\circ} \mathrm{C}$, time of fermentation: ca. $30 \mathrm{hrs.}$, Butanol and ethanol were determined by the method of Johnson, 7 ) and acetone by the method of Goodwin. ${ }^{8}$ )

* The same solvent yield was obtained even when phage HM $2\left(10^{2}\right.$ PFU $)$ was added in the presence of OTC $(15 \mu \mathrm{g} /$ $\mathrm{ml}$ ).

** The same solvent yield was obtained even when phage HM $2\left(10^{8}\right.$ PFU) was added in the absence of OTC.

7) M. J. Johnson, Ind. Eng. Chem. Anal. Ed., 4, 20 (1932). per plate were used, and no lysis occurred even when $10^{8}$ PFU were added to the broth culture of the strains.

Table I shows the solvents yield of the mutants. The strains of type $B$ resembled their parent strain in their solvent yield, whereas the strains of type A produced a slightly higher proportion of acetone. Oxytetracycline had a slight phagicidal action, but had no effect on the rate of adsorption of the phage to the host bacteria. Details of these studies will be reported later.

These findings suggest the possibility that antibiotic-resistant mutant may be employed for the suppression of phage growth not only in butanol fermentation but also in other industrial fermentations.

\section{Motoyoshi HoNGO Hideo ONo* Keiko Kono Akira Murata}

Laboratory of Applied Microbiology

Department of Agricultural Chemistry

Kyushu University

Fukuoka, Japan

Received January 10, 1966

8) L. F. Goodwin, J. Am. Chem. Soc., 42, 39 (1920).

* Present address: Takeda Chemical Industries, Ltd., Osaka. 